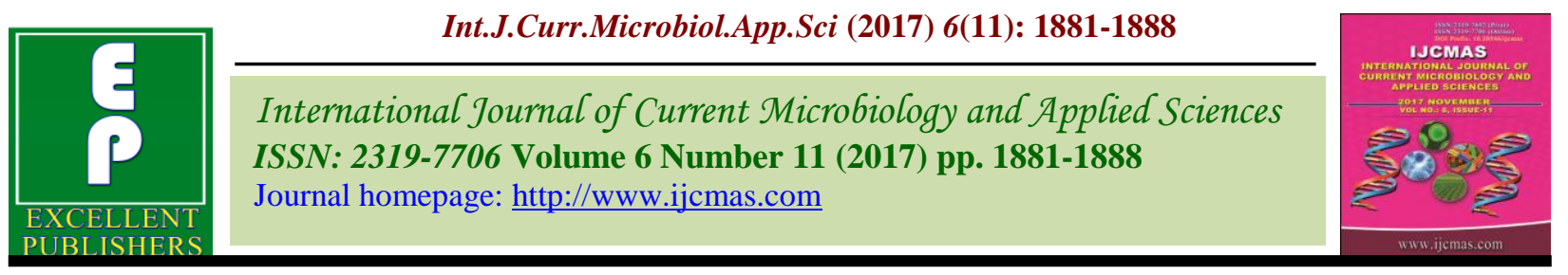

Original Research Article

https://doi.org/10.20546/ijcmas.2017.611.224

\title{
A Comparison of Antibody Titers in Brucellosis Affected Vaccinated Cattle, Unvaccinated Infected Cattle and Healthy Vaccinated Cattle by Agglutination Assays
}

\author{
Sugandha Raj ${ }^{1}$, Hari Mohan Saxena ${ }^{1 *}$ and S.T. Singh ${ }^{2}$ \\ ${ }^{1}$ Department of Veterinary Microbiology, Guru Angad Dev Veterinary and \\ Animal Sciences University, Ludhiana, Punjab, India \\ ${ }^{2}$ Department of Animal Genetics and Breeding, Guru Angad Dev Veterinary and Animal \\ Sciences University, Ludhiana, Punjab, India \\ *Corresponding author
}

\section{A B S T R A C T}

K e y w o r d s
Antibody titer,
Brucellosis, Indirect
Hemagglutination
Assay,
Microagglutination
test, Standard Tube
Agglutination Test.
Article Info
Accepted:
15 September 2017
Available Online:
10 November 2017

The titers of anti-Brucella antibodies in naturally Brucellosis affected unvaccinated cattle, previously vaccinated infected cattle and normal healthy vaccinated cattle were estimated by common agglutination assays MAT, STAT, IHA. The mean antibody titers $\left(\log _{10}\right)$ were found to be $2.856+0.47$ by MAT, $2.041+0.39$ by STAT and $2.471+0.51$ by IHA, respectively in case of Brucellosis affected cattle which had been vaccinated during calf hood. The mean titers in case of naturally infected cattle which had never been vaccinated were $3.759+0.35$ by MAT, $3.408+0.32$ by STAT and $3.508+0.32$ by IHA, respectively. The mean titers in healthy unaffected cattle vaccinated during calf hood were as follows $1.401+0.31$ by MAT, $1.401+0.15$ by STAT, and $1.45+0.16$ by IHA, respectively. It was interesting to find that the antibody titers in naturally affected cattle which had never been vaccinated previously were very significantly $(p<0.01)$ higher than those of Brucellosis affected cattle which had been vaccinated during calfhood and normal healthy vaccinated cattle unaffected by the disease. The mean titer in Brucellosis affected cattle which had been vaccinated during calfhood was very significantly $(\mathrm{p}<0.01)$ higher than that of normal healthy vaccinated cattle unaffected by the disease.

\section{Introduction}

Brucellosis is an important re-emerging zoonotic disease caused by Brucella organisms. It is pathogenic for a wide variety of animals such as cattle, swine, goats, sheep and dogs. Brucellosis is endemic in India and is prevalent in all parts of the country. About 500,000 cases of human brucellosis are estimated to occur worldwide every year. It causes heavy economic loss to the animal industry through delayed conception, lateterm abortions and retention of placenta and temporary or permanent infertility (Kollannur et al., 2007) in females and orchitis and epididymitis in males, with excretion of organisms in semen, uterine discharges, and in milk (Godfroid et al., 2013). It is estimated that due to Brucellosis, there is a loss of US\$58.8 million per year in India (Kollannur et al., 2007). The occurrence of this disease varies from $10 \%$ in marginal herds to $50 \%$ in organized farms. The socio-economic impact of the disease was estimated to run over 
Rs.500 Crores annually (Jain et al., 2013; Pandeya et al., 2013). The vaccine against Brucellosis widely used for cattle is derived from the smooth live vaccine strain S19. It has proven to be very useful under most conditions but has some undesirable traits also (Moriyon et al., 2004). Although vaccination with the live attenuated Brucella abortus strain 19 is believed to be effective in preventing Brucellosis in cattle and buffaloes, it is not uncommon to find adult cattle infected with Brucellosis which had been vaccinated in calf hood with $\mathrm{S} 19$ vaccine. In the absence of a marker vaccine and DIVA assay for bovine Brucellosis, it becomes difficult to assess whether the anti-Brucella antibody titers in an animal are due to vaccination or due to infection.

Although there is vast information on various aspects of bovine Brucellosis in the available literature, there is hardly any systematic study on the comparison of antibody levels between infected and vaccinated animals. We therefore compared the antibody titers of different categories of animals to investigate if titers alone could indicate whether the animal is infected or vaccinated or infected despite vaccination. The present study offers valuable insight into the status of humoral immune response in Brucellosis affected or vaccinated cattle which could help in devising appropriate control strategies for this dreaded zoonosis.

\section{Materials and Methods}

Permission of the Institutional Animal Ethics Committee (IAEC) was obtained and CPCSE guidelines were followed in all animal experiments.

\section{Collection of serum}

Blood samples were collected from naturally infected clinical cases of Brucellosis in cattle which had never been vaccinated in villages in and around Ludhiana district and from Brucellosis affected cattle which had been vaccinated during calf hood, normal healthy (uninfected) vaccinated cattle and healthy unvaccinated calves from an organized dairy farm from Ludhiana. Sera were separated from clotted blood and stored at $-20^{\circ} \mathrm{C}$ till further use for studying the antibody response of the animals.

\section{Rose Bengal Plate Test (RBPT)}

Equal volumes $(25 \mu 1$ each) of RBPT colored antigen (Punjab Veterinary Vaccine Institute, Ludhiana) and test serum were mixed on a clean glass slide (Morgan et al., 1978). The slide was observed till $3 \mathrm{~min}$. for formation of clumps. Formation of clumps indicated a positive reaction while the absence of clear clumps was considered as a negative reaction.

\section{Estimation of antibody titers by Standard Tube Agglutination Test (STAT)}

The standard method recommended by OIE (2004) was followed. Ten agglutination tubes were labeled and placed in rack.

Then $0.8 \mathrm{ml}$ of $0.5 \%$ carbol saline was added to the first tube of the series. $0.5 \mathrm{ml}$ of carbol saline was added to the rest of the tubes except 8, 9 and 10 which were kept as controls, containing $1.25,1.50$ and $1.75 \mathrm{ml}$ of carbol saline, respectively.

$0.2 \mathrm{ml}$ serum was added to the first tube and the contents were mixed. $0.5 \mathrm{ml}$ of plain Brucella abortus antigen (Punjab Veterinary Vaccine Institute, Ludhiana) was added to the first tube and final dilutions were made in ratios of 1:10, 1:20, 1:40, 1:80 and so on. To the control tubes 8,9 and 10, Brucella abortus plain antigen $0.75,0.50$ and $0.25 \mathrm{ml}$, respectively was added (Table 1 ). Tubes were incubated for 24 hours at $37^{\circ} \mathrm{C}$ and results 
were compared with the antigen control tube showing 50\% agglutination. The highest serum dilution showing 50\% agglutination was taken as the end point for the titer serum. A titer of 1:40 or above was considered positive.

\section{Controls}

Tube no. $8-25 \%$ agglutination

Tube no. 9- 50\% agglutination

Tube no. $10-75 \%$ agglutination

\section{Microtiter Plate Agglutination Test (MAT)}

MAT was performed as per the method of William and Whittemore (1997)

Serum samples were serially two fold diluted in phosphate buffer saline to make final volume of $100 \mu \mathrm{l}$ in a 96 well $\mathrm{U}$ bottom microtiter plate (Tarsons).

Equal volume of $100 \mu \mathrm{l}$ of Plain Brucella abortus antigen (Punjab Veterinary Vaccine Institute, Ludhiana) was added to each well.

Negative control well containing $100 \mu \mathrm{l}$ Phosphate buffer saline and $100 \mu \mathrm{l}$ antigen was also marked.

The plate was sealed and mixed gently for 20 seconds and incubated at $37^{\circ} \mathrm{C}$ for $24 \mathrm{hr}$ followed by incubation at $4^{\circ} \mathrm{C}$ for 1 hour.

Matt formation was considered as a positive reaction while button formation was considered as a negative reaction. Titers $\left(\log _{10}\right.$ values) were expressed as reciprocal of the highest dilution of sera showing 50 percent agglutination.

\section{Indirect Haemagglutination Test (IHA)}

The Method of Sawada et al., (1982) was followed.

\section{Sheep Red Blood Cells (sRBCs)}

Sheep blood was collected aseptically into Alsever's solution $(1: 1)$ by jugular vein puncture, and kept at $4^{\circ} \mathrm{C}$ for 7 days before further processing. Blood was centrifuged at 1500-2000 rpm for $10 \mathrm{~min}$ to settle the RBCs. The packed RBCs were washed three times with 5-6 volumes of chilled normal saline solution (NSS) by centrifugation. The 10\% suspension of RBCs prepared in chilled NSS was stored at $4^{\circ} \mathrm{C}$.

\section{Fixation of RBCs and treatment with tannic acid}

One percent solution of glutaraldehyde was prepared in NSS and stored at $4^{\circ} \mathrm{C}$ for $30 \mathrm{~min}$ with intermittent gentle stirring.

The sensitized sRBCs were packed by centrifugation at $1500-2000 \mathrm{rpm}$ for $10 \mathrm{~min}$ at room temperature followed by three washes in normal saline for removal of glutaraldehyde. This was resuspended in the same buffer containing 0.1 percent Sodium Azide to yield a 10 percent suspension of sRBCs. The glutaraldehyde fixed sRBCs (GsRBCs) were stored at $4^{\circ} \mathrm{C}$.

10 percent suspension of G-sRBCs was mixed with equal volume of Phosphate Buffered Saline containing 0.005 percent tannic acid (w/v), and incubated at $37^{\circ} \mathrm{C}$ with occasional shaking. The tanned G-sRBCs (TG-sRBCs) were pelleted by centrifugation at $650 \mathrm{x} \mathrm{g}$ for $10 \mathrm{~min}$ at room temperature and washed three times with PBS to yield a 10 percent suspension.

\section{Preparation of antigen}

The antigen prepared as described earlier was heated at $56^{\circ} \mathrm{C}$ for $30 \mathrm{~min}$ in a water bath with frequent shaking. Heat treated suspension was centrifuged at $8000 \mathrm{rpm}$ for $15 \mathrm{~min}$ at $4^{\circ} \mathrm{C}$. 
The clear supernatant was separated and stored at $-20^{\circ} \mathrm{C}$.

\section{Sensitization of TG-s RBCs with antigen}

One volume of packed RBCs and 15 volumes of the antigen, were mixed and incubated for $2 \mathrm{hrs}$ at $37^{\circ} \mathrm{C}$ in a water bath with frequent shaking. The sensitized cells prepared were washed three times with NSS by centrifugation at $2500 \mathrm{rpm}$ for $10 \mathrm{~min}$. After the final wash, the packed cells were resuspended in chilled NSS to obtain 1 percent suspension.

\section{Adsorption of serum samples}

To remove the heterophile antibodies, all the serum samples were adsorbed with packed sRBCs (1 volume) for 2 hours at $37^{\circ} \mathrm{C}$ with periodic shaking before the test proper. The RBCs were removed by centrifugation.

The suspension was centrifuged at $600 \mathrm{x} \mathrm{g}$ for $15 \mathrm{~min}$ at $4^{\circ} \mathrm{C}$ in a refrigerated centrifuge. The suspension was collected and used for the test.

\section{Test protocol for IHA}

Phosphate buffered saline $(160 \mu l)$ and inactivated adsorbed serum $(40 \mu \mathrm{l})$ was added to the first well ( 1 in 4 dilutions) and $100 \mu$ of PBS was added to all the wells. The plates were shaken and left at room temperature for 2 hr. Coarse agglutination of RBCs (matt formation) indicated a positive result and formation of small button of deposited cells was considered as a negative result.

\section{Controls}

Three controls were included in the test:

Antigen control: $100 \mu 1$ of sensitized and adsorbed RBCs.
RBC control: $100 \mu$ of $1: 4$ dilution of serum and $100 \mu l$ of sensitized RBCs.

Serum control: $100 \mu$ of untreated erythrocytes and $100 \mu$ l of test serum.

\section{Statistical analysis}

Data pertaining to serum antibody titers by STAT, MAT and IHA were statistically analyzed by ANOVA.

\section{Results and Discussion}

The titers of anti-Brucella antibodies in naturally Brucellosis affected unvaccinated cattle, previously vaccinated infected cattle and normal healthy vaccinated cattle were estimated by common agglutination assays MAT, STAT and IHA. The mean antibody titers $(\log 10)$ were found to be $2.856+0.47$ by MAT, $2.041+0.39$ by STAT and $2.471+0.51$ by IHA, respectively in case of Brucellosis affected cattle which had been vaccinated during calf hood (Table 2). The mean titers in case of naturally infected cattle which had never been vaccinated were $3.759+0.35$ by MAT, $3.408+0.32$ by STAT and $3.508+0.32$ by IHA, respectively (Table 3 ). The mean titers in healthy unaffected cattle previously vaccinated during calf hood were as follows $1.401+0.31$ by MAT, $1.401+0.15$ by STAT, and $1.45+0.16$ by IHA, respectively (Table 4 , Fig. 1).

The mean titer in unvaccinated infected cattle was very significantly $(\mathrm{p}<0.01)$ higher than that of Brucellosis affected vaccinated cattle. The mean titer of Brucellosis affected vaccinated cattle was very significantly $(p<0.01)$ higher than that of normal healthy vaccinated cattle. The mean titer of unvaccinated infected cattle was very significantly $(p<0.01)$ higher than that of healthy vaccinated cattle. It was interesting to find that the antibody titers in naturally 
affected cattle which had never been vaccinated previously were very significantly higher than those of Brucellosis affected cattle which had been vaccinated earlier and normal healthy vaccinated cattle unaffected by the disease by all the three assays (MAT, STAT, and IHA).

Assessment of immunological data from Brucella infected cattle can be helpful in charting the disease process, diagnosis and prognosis and may help in understanding the pathophysiology of disease. It has been reported earlier (Mohan et al., 2016) that infected animals have very high titers of antibodies compared to the vaccinated animals. However, in the absence of an assay for differentiation of infected from vaccinated animals (DIVA assay), it is not possible to determine whether these antibodies are protective or not and are induced by the vaccine or due to response of the animal to acute infection and whether they are of any relevance to prognosis.

Fig.1 Antibody titers in brucellosis infected or vaccinated cattle

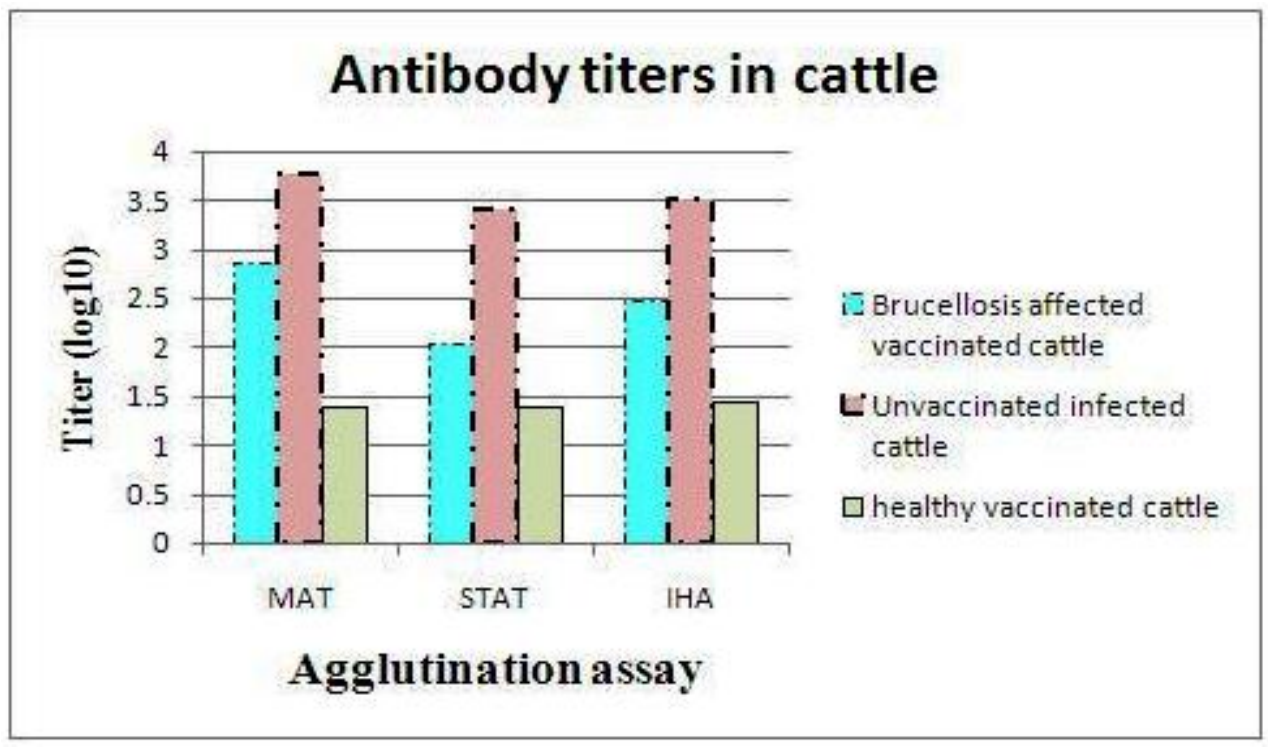

Table.1 STAT protocol

\begin{tabular}{|c|c|c|c|c|}
\hline Tube no. & Carbol saline (ml) & Test serum $(\mathrm{ml})$ & $\begin{array}{l}\text { B. abortus plain } \\
\text { antigen }(\mathrm{ml})\end{array}$ & Final dilution \\
\hline 1 & 0.8 & 0.2 & 0.5 & $1: 10$ \\
\hline 2 & 0.5 & \multirow{9}{*}{$\begin{array}{c}\text { Serial dilution was } \\
\text { performed after } \\
\text { thorough mixing. } 0.5 \\
\text { ml of the contents was } \\
\text { transferred from tube } \\
\text { no. } 1 \text { to the next tube } \\
\text { up to tube no.7.Finally } \\
0.5 \text { ml of the contents } \\
\text { was discarded from } \\
\text { tube no. } 7\end{array}$} & 0.5 & $1: 20$ \\
\hline 3 & 0.5 & & 0.5 & $1: 40$ \\
\hline 4 & 0.5 & & 0.5 & $1: 80$ \\
\hline 5 & 0.5 & & 0.5 & $1: 160$ \\
\hline 6 & 0.5 & & 0.5 & $1: 320$ \\
\hline 7 & 0.5 & & 0.5 & $1: 640$ \\
\hline 8 & 1.25 & & 0.75 & \\
\hline 9 & 1.50 & & 0.50 & \\
\hline 10 & 1.75 & & 0.25 & \\
\hline
\end{tabular}


Table. 2 Antibody titers in brucellosis affected vaccinated cattle by agglutination assays

\begin{tabular}{|c|c|c|c|c|}
\hline \multirow[t]{2}{*}{ S. No } & \multirow[t]{2}{*}{ Animal number } & \multicolumn{3}{|c|}{ Antibody titer } \\
\hline & & MAT & STAT & IHA \\
\hline 1 & B1 & 2.505 & 1.602 & 2.205 \\
\hline 2 & B2 & 2.806 & 1.903 & 2.204 \\
\hline 3 & B3 & 2.505 & 2.204 & 1.903 \\
\hline 4 & B4 & 2.505 & 1.602 & 2.505 \\
\hline 5 & B5 & 2.806 & 1.903 & 2.204 \\
\hline 6 & B6 & 3.408 & 2.204 & 3.408 \\
\hline 7 & B7 & 3.709 & 2.204 & 3.408 \\
\hline 8 & B8 & 2.505 & 1.602 & 2.204 \\
\hline 9 & B9 & 2.806 & 1.903 & 2.806 \\
\hline 10 & B10 & 3.408 & 2.505 & 2.806 \\
\hline 11 & B11 & 2.505 & 1.602 & 2.505 \\
\hline 12 & B12 & 2.204 & 1.903 & 1.903 \\
\hline 13 & B13 & 2.505 & 1.602 & 2.404 \\
\hline 14 & B14 & 2.204 & 1.602 & 2.204 \\
\hline 15 & B15 & 3.107 & 2.505 & 2.806 \\
\hline 16 & $\mathrm{~B} 16$ & 3.709 & 2.505 & 3.408 \\
\hline 17 & B17 & 2.505 & 1.602 & 2.404 \\
\hline 18 & B18 & 3.107 & 1.903 & 3.107 \\
\hline 19 & B19 & 2.806 & 1.903 & 1.903 \\
\hline 20 & $\mathrm{~B} 20$ & 2.505 & 2.505 & 2.204 \\
\hline 21 & B21 & 3.408 & 2.806 & 3.107 \\
\hline 22 & B22 & 2.505 & 2.204 & 1.903 \\
\hline 23 & B23 & 3.709 & 2.806 & 1.903 \\
\hline 24 & B24 & 2.806 & 1.903 & 1.903 \\
\hline \multicolumn{2}{|c|}{ Mean \pm SD } & $2.856 \pm 0.47$ & $2.041 \pm 0.39$ & $2.471 \pm 0.51$ \\
\hline
\end{tabular}

Table.3 Antibody titers in brucellosis infected unvaccinated cattle

\begin{tabular}{|c|c|c|c|}
\hline Animal No. & MAT & STAT & IHA \\
\hline A I & 3.408 & 3.107 & 3.107 \\
\hline A II & 3.709 & 3.107 & 3.408 \\
\hline A III & 4.010 & 3.709 & 3.709 \\
\hline A IV & 3.709 & 3.709 & 3.408 \\
\hline A V & 3.408 & 3.107 & 3.408 \\
\hline A VI & 4.311 & 3.709 & 4.010 \\
\hline Mean $\mathbf{\text { SD }}$ & $\mathbf{3 . 7 5 9} \pm \mathbf{0 . 3 5}$ & $\mathbf{3 . 4 0 8} \pm \mathbf{0 . 3 2}$ & $\mathbf{3 . 5 0 8} \pm \mathbf{0 . 3 1}$ \\
\hline
\end{tabular}


Table.4 Antibody titers in healthy vaccinated cattle by agglutination assays

\begin{tabular}{|l|l|l|l|}
\hline Animal no. & MAT & STAT & IHA \\
\hline C1 & 1.602 & 1.301 & 1.301 \\
\hline C2 & 1.301 & 1.301 & 1.602 \\
\hline C 3 & 1.301 & 1.602 & 1.602 \\
\hline C4 & 1.903 & 1.301 & 1.602 \\
\hline C5 & 1.000 & 1.301 & 1.301 \\
\hline C6 & 1.301 & 1.602 & 1.301 \\
\hline Mean + SD & $\mathbf{1 . 4 0 1} \pm \mathbf{0 . 3 1}$ & $\mathbf{1 . 4 0 1} \pm \mathbf{0 . 1 5}$ & $\mathbf{1 . 4 5 1} \pm \mathbf{0 . 1 6}$ \\
\hline
\end{tabular}

Numerous outer and inner membrane, cytoplasmic, and periplasmic protein antigens of Brucella have been characterized, yet the antigen that dominates the antibody response is Lipopolysaccharide (LPS). Some antigens are recognized by the immune system during infection and are potentially useful in diagnostic tests. The L7/L12 ribosomal proteins are important in stimulating cellmediated responses (Oliveira and Splitter, 1994).

The role of humoral immunity against intracellular bacterial infections is limited and may not be protective. Antibody mediated opsonization by immunoglobulins ( $\operatorname{IgM}$, IgG1, IgG2a and IgG3) enhances phagocytic uptake of bacteria, limiting the level of initial infection with Brucella but has little effect on intracellular course of infection (Bellaire et al., 2005; Baldwin and Goenka, 2006).

Since the infected animals in the first group were the ones who had already been vaccinated during calf hood, the infection in these animals may suggest that the vaccine was unable to induce adequate protective levels of antibody. Secondly, the heightened antibody response after infection in vaccinated animals may indicate a secondary immune response to Brucella antigens.

The anti-Brucella antibody titers in naturally affected unvaccinated cattle were very significantly higher than those of Brucellosis affected vaccinated cattle and normal healthy vaccinated cattle unaffected by the disease as determined by three agglutination assays (MAT, STAT, and IHA).

\section{Conflict of interest}

The authors declare that there is no conflict of interest.

\section{Acknowledgement}

The study was funded by a grant under RKVY scheme (PI: H M Saxena)

\section{References}

Baldwin, CL and Goenka R (2006) Host immune responses to the intracellular bacterium Brucella: does the bacterium instruct the host to facilitate chronic infection? Crit. Rev. Immunol. 26: 407-442.

Bellaire, BH., Roop, RM $2^{\text {nd }}$ and Cardelli JA (2005) Opsonized virulent Brucella abortus replicates within non acidic, endoplasmic reticulum - negative, LAMP-1 positive phagosomes in human monocytes. Infect. Immun. 73: 3702-3713.

Godfroid, J., Garin-Bastuji, B., Saegerman, C and Blasco, JM (2013). Brucellosis in Terrestrial Wildlife. Rev. Sci. Tech. OIE 32(1): 27-42.

Jain, U., Bisht, B., Sahzad, P and Dwivedi K 
(2013). Outbreak of Brucellosis in buffaloes aborted in a village Mahuan, district Mainpuri, UP, India-A case report. Vet. World 51-52.

Kollannur, JD., Rathore, R and Chauhan, RS (2007). Epidemiology and economics of Brucellosis in animals and its zoonotic significance. Proceedings of XIII International Congress in Animal Hygiene. International Society for Animal Hygiene: 466-68.

Mohan, A., Saxena, HM and Malhotra P (2016). A comparison of titers of antiBrucella antibodies of naturally infected and healthy vaccinated cattle by standard tube agglutination test, microtiter plate agglutination test, indirect hemagglutination assay, and indirect enzyme-linked immune sorbent assay. Vet. World 9(7): 717722.

Moriyon, I., Grillo, MJ., Monreal, D., Gonzalez, D., Marin, C., Lopez-Goni,
I., Mainar-Jaime, RC., Moreno, E and Blasco, JM (2004) Rough vaccines in animal brucellosis: Structural and genetic basis and present status. Vet. Res., 35(1): 1-38.

OIE World Organization for Animal Health. 2004. Bovine brucellosis, section 2.3. Manual of Standards for Diagnostic Tests and Vaccines. $5^{\text {th }}$ edition.

Oliveira, SC and Splitter, GA (1994) Subcloning and expression of Brucella abortus L7/L12 ribosomal gene and Tlymphocyte recognition of the recombinant protein. Infect. Immun., 62: 5201-5204.

Pandeya, YR., Joshi DD., Dhakal, S., Ghimire, L., Mahato, BR., Chaulagain, S., Satyal, RC and Sah, SK (2013) Seroprevalance of brucellosis in different animal species of Kailali district, Nepal. Int. J. Infect. Microbiol. 2(1): 22-25.

\section{How to cite this article:}

Sugandha Raj, Hari Mohan Saxena and Singh, S.T. 2017. A Comparison of Antibody Titers in Brucellosis Affected Vaccinated Cattle, Unvaccinated Infected Cattle and Healthy Vaccinated Cattle by Agglutination Assays. Int.J.Curr.Microbiol.App.Sci. 6(11): 1881-1888. doi: https://doi.org/10.20546/ijcmas.2017.611.224 